\title{
3 \\ Quantitative Cranio-Morphology \\ at Man Bac
}

\author{
Hirofumi Matsumura
}

Department of Anatomy, Sapporo Medical University, Japan

The aim of this chapter is to quantitatively assess cranial morphology of the Man Bac assemblage and explore any evidence for biological relationships between Man Bac and surrounding populations dating from prehistoric through to more recent times. An assessment of the morphometric affinities presented here addresses the issue of the origin of this group of neolithic people in northern Vietnam.

\section{MATERIALS AND METHODS}

Of the human remains excavated from Man Bac between 1999 and 2007, comprehensive sets of cranial and mandibular measurements were available for 17 adult males and 13 females. A maximum of 32 measurements, and five indices, were recorded for each cranium and mandible (a complete set was not always available) based on Martin's definitions (see Bräuer, 1988) and are presented in the Appendix to this chapter. Male skulls representative of the sample are shown in Figure 3.1 and Table 3.1 provides a basic statistical description of the cranial and mandibular series based on these measurements. Note that Table 3.1 provides summary data for two recognised Man Bac male subgroups (this is discussed below) as well as the total male sample and complete (both sexes) sample.

Of the cranial assemblage, 17 male skulls are utilised for craniometric analysis. The craniometric affinities among the comparison samples are assessed using Qmode correlation coefficients (Sneath and Sokal, 1973). The comparative samples are listed in Table 3.2, which includes both archaeological and modern samples from East/Southeast Asia and the Pacific. To aid interpretation of phenotypic affinities between the samples, un-rooted tree diagrams were generated using the Neighbour Joining method (Saitou and Nei, 1987), applied to the distance (1-r) matrix of Q-mode correlation coefficients $(\mathrm{r})$. This procedure was undertaken using the software package "Splits Tree Version 4.0" provided by Huson and Bryant (2006).

\section{RESULTS}

The majority of the Man Bac cranial series can be characterised as having a relatively narrow and flat face with round orbits (Figure $3.1 \mathrm{left}$ ). However, some individuals present quite different features, such as a dolichocephalic cranium with 


\section{H. MATSUMURA}

a prominent glabella and a low and wide face (Figure 3.1, right). Since such visually clear morphological variation among the Man Bac cranial series implies the
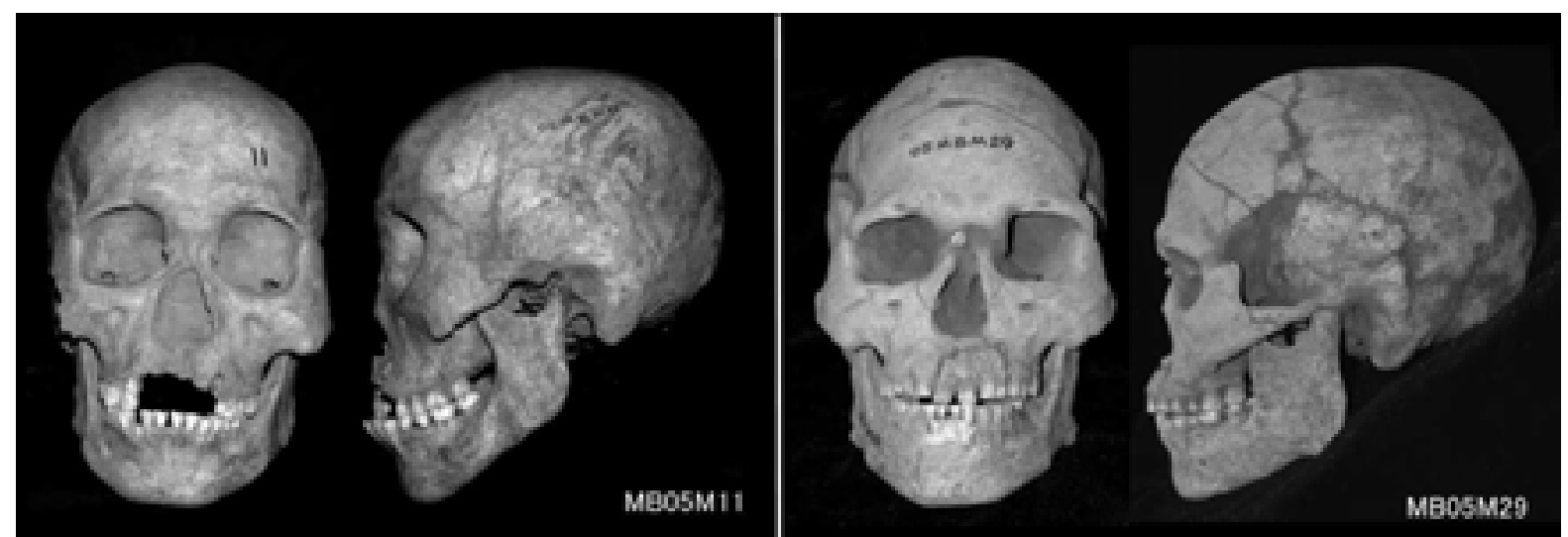

Figure 3.1 Views of representative skulls from the site of Man Bac.

possibility of genetic heterogeneity, multivariate craniometric comparisons were carried out in order to both confirm and assess the degree of phenotypic variation within the Man Bac adult male series.

In order to utilise the greatest number of individual specimens, given differential preservation and consequent availability of measurements, nine cranial measurements (Martin's 1, 8, 9, 45, 48, 51, 52, 54 and 55) were selected for calculating the Q-mode correlation coefficient. A complete data set without any missing values was derived for $14 / 17$ of the Man Bac male adult series. Table 3.3 (upper right triangle) provides the distance matrix (1-r) transformed from the Qmode correlation coefficients ( $\mathrm{r}$ ) thus computed.

The result of the Neighbour Joining analysis applied to the distance matrix of Qmode correlation coefficients is presented in Figure 3.2. The non-rooted tree in this figure depicts an apparent divergence into two major clusters. One consists of the majority of Man Bac individuals ( $n=9$ ) which have branched from neolithic, Metal Period and modern samples from East and Southeast Asia. In this clustering pattern seven Man Bac specimens are more closely associated with the Metal Period Dong Son Vietnamese among the range of modern Southeast Asian samples. This sub-cluster contains the neolithic and Metal Period sample of Ban Chiang crania from northern Thailand. The modern Vietnamese sample, together with another Man Bac specimen, branches from this sub-cluster. The Hoabinhian, Australian and Melanesian samples form another major cluster, which includes five Man Bac individuals, together with the Jomon.

In the next step of analysis cranial affinities were assessed using group-average measurements for the two identified Man Bac samples, utilising 17 male cranial specimens. As the analysis using the individual dataset yielded a clear dichotomisation of the Man Bac adult male series, five individuals were treated as a separate group designated 'Man Bac 1', while the remaining specimens were combined with other incomplete male crania and labelled 'Man Bac 2'. The descriptive statistics for these two sub-samples is given in Table 3.2. Q-mode correlation coefficients were calculated using the new cranial data set consisting of 16 measurements (Martin's: M1, M8, M9, M17, M43(1), M43c, M45, M46b, M46c, 
M57, M57a, M48, M51, M52, M54, M55). A distance matrix (1-r) transformed from the Q-mode correlation coefficients thus calculated are given in Table 3.3 (left lower triangle). Figure 3.3 depicts an un-rooted tree using the Neighbour Joining method based on the distance matrix of Q-mode correlation coefficients. 'Man Bac 1' is tightly connected with the early Vietnamese samples including the Hoabinhian, Bac Son and Da But (Con Co Ngua) series. These samples form a mega cluster together with the Australo-Melanesian, Gua Cha (Malaysia) and Jomon (Japan) samples. On the other hand, the 'Man Bac 2' and Dong Son Vietnamese, forming a sub-cluster together with Ban Chiang (Thailand) and modern Vietnamese, are linked closely with another major cluster consisting of the neolithic to modern period samples from East/Southeast Asia, as well as the Neolithic Weidun sample from China.

Table 3.1 Cranial and mandibular measurements $(\mathrm{mm})$ and indices for the Man Bac people.

\begin{tabular}{|c|c|c|c|c|c|c|c|c|c|c|c|c|}
\hline \multirow{2}{*}{ Martin's No and measurement } & \multicolumn{3}{|c|}{ Man Bac 1 (males) } & \multicolumn{3}{|c|}{ Man Bac 2 (males) } & \multicolumn{3}{|c|}{ Man Bac all (males) } & \multicolumn{3}{|c|}{ Man Bac all (females) } \\
\hline & $\mathrm{n}$ & $\mathrm{M}$ & SD & $\mathrm{n}$ & $\mathrm{M}$ & SD & $\mathrm{n}$ & $\mathrm{M}$ & SD & $\mathrm{n}$ & $\mathrm{M}$ & SD \\
\hline 1 Max. cranial length & 5 & 185.6 & 4.0 & 11 & 179.7 & 5.7 & 16 & 181.6 & 5.8 & 12 & 174.5 & 6.0 \\
\hline 5 Basion-nasion length & 5 & 102.6 & 4.5 & 5 & 99.4 & 6.7 & 10 & 101.0 & 5.6 & 5 & 95.0 & 4.8 \\
\hline 8 Max. cranial breadth & 5 & 143.6 & 6.8 & 11 & 142.4 & 5.7 & 16 & 142.8 & 5.8 & 12 & 134.8 & 3.3 \\
\hline 9 Min. frontal breadth & 5 & 100.4 & 5.9 & 11 & 98.5 & 4.0 & 16 & 99.1 & 4.6 & 12 & 94.0 & 5.0 \\
\hline 10 Max. frontal breadth & 5 & 114.6 & 9.0 & 8 & 118.8 & 5.8 & 13 & 117.2 & 7.2 & 10 & 113.8 & 4.6 \\
\hline 12 Max. occipital breadth & 5 & 113.4 & 5.9 & 8 & 109.4 & 4.9 & 13 & 110.9 & 5.4 & 8 & 108.5 & 3.9 \\
\hline 17 Basion-bregma height & 5 & 143.8 & 6.3 & 6 & 140.0 & 8.9 & 11 & 141.7 & 7.7 & 5 & 134.2 & 10.7 \\
\hline 29 Frontal chord & 5 & 116.4 & 2.7 & 8 & 111.5 & 3.5 & 13 & 113.4 & 3.9 & 10 & 107.3 & 5.6 \\
\hline 30 Parietal chord & 5 & 118.6 & 3.8 & 8 & 114.5 & 6.7 & 13 & 116.1 & 6.0 & 10 & 111.3 & 7.8 \\
\hline 31 Occipital chord & 5 & 105.0 & 2.8 & 7 & 106.0 & 5.7 & 12 & 105.6 & 4.6 & 6 & 100.8 & 5.8 \\
\hline 40 Basion-prosthion length & 5 & 102.2 & 0.8 & 5 & 99.0 & 2.7 & 10 & 100.6 & 2.5 & 5 & 90.8 & 3.3 \\
\hline 43 Upper facial breadth & 5 & 113.0 & 5.1 & 11 & 110.5 & 5.7 & 16 & 111.3 & 5.5 & 8 & 105.5 & 4.1 \\
\hline 45 Bizygomatic breadth & 5 & 142.0 & 6.2 & 10 & 141.6 & 6.9 & 15 & 141.7 & 6.5 & 8 & 132.5 & 7.1 \\
\hline 46 Bimaxillary breadth & 5 & 109.0 & 4.5 & 10 & 108.2 & 6.1 & 15 & 108.5 & 5.5 & 6 & 103.3 & 4.1 \\
\hline 48 Upper facial height & 5 & 68.8 & 3.1 & 10 & 71.0 & 4.0 & 15 & 70.3 & 3.8 & 7 & 68.0 & 3.4 \\
\hline 51 Orbital breadth & 5 & 44.2 & 1.9 & 9 & 41.6 & 2.1 & 14 & 42.5 & 2.3 & 8 & 41.0 & 1.3 \\
\hline 52 Orbital height & 5 & 33.0 & 2.0 & 11 & 35.5 & 1.8 & 16 & 34.7 & 2.1 & 9 & 34.6 & 1.3 \\
\hline 54 Nasal breadth & 5 & 28.8 & 3.1 & 11 & 28.1 & 1.4 & 16 & 28.3 & 2.0 & 8 & 25.9 & 2.6 \\
\hline 55 Nasal height & 5 & 51.0 & 2.5 & 10 & 54.1 & 3.5 & 15 & 53.1 & 3.5 & 7 & 51.6 & 3.1 \\
\hline 60 Upper alveolar length & 5 & 54.2 & 0.8 & 10 & 53.0 & 3.0 & 15 & 53.4 & 2.5 & 7 & 52.4 & 3.7 \\
\hline 61 Upper alveolar breadth & 5 & 66.6 & 2.1 & 10 & 67.0 & 3.5 & 15 & 66.9 & 3.0 & 6 & 63.5 & 3.5 \\
\hline 8:1 Cranial index & 5 & 77.5 & 5.2 & 11 & 79.3 & 4.2 & 16 & 78.7 & 4.4 & 10 & 77.9 & 4.4 \\
\hline 48:45 Upper facial index & 5 & 48.6 & 4.2 & 10 & 45.7 & 16.3 & 15 & 46.6 & 13.4 & 6 & 52.4 & 1.3 \\
\hline 43(1) Frontal chord & 5 & 104.2 & 5.1 & 8 & 103.5 & 6.6 & 13 & 103.8 & 5.9 & & & \\
\hline 43c Frontal subtense & 5 & 16.3 & 5.1 & 8 & 14.6 & 3.2 & 13 & 15.2 & 3.9 & & & \\
\hline 57 Simotic chord & 5 & 9.6 & 1.6 & 5 & 10.2 & 2.6 & 10 & 9.9 & 2.1 & & & \\
\hline 57a Simotic subtense & 4 & 3.2 & 0.7 & 5 & 3.0 & 1.9 & 9 & 3.1 & 1.4 & & & \\
\hline 46b Zygomaxillary chord & 5 & 107.6 & 6.1 & 6 & 107.0 & 6.8 & 11 & 107.3 & 6.2 & & & \\
\hline 46c Zygomaxillary subtense & 5 & 22.6 & 4.1 & 6 & 22.5 & 4.7 & 11 & 22.5 & 4.2 & & & \\
\hline 43c:43(1) Frontal index & 5 & 15.8 & 5.5 & 8 & 14.1 & 2.8 & 13 & 14.7 & 3.9 & & & \\
\hline 57a:57 Simotic index & 4 & 33.6 & 1.7 & 5 & 26.6 & 12.4 & 9 & 29.7 & 9.6 & & & \\
\hline 46c:46b Zygomaxillary index & 5 & 21.1 & 4.2 & 6 & 20.9 & 3.8 & 11 & 21.0 & 3.8 & & & \\
\hline 66 Bigonial breadth & 5 & 104.6 & 7.5 & 9 & 105.9 & 9.4 & 14 & 105.4 & 8.5 & 8 & 96.3 & 6.3 \\
\hline 68 Mandibular length & 5 & 83.2 & 1.6 & 9 & 80.8 & 4.1 & 14 & 81.6 & 3.5 & 8 & 74.5 & 5.5 \\
\hline 69 Symphyseal height & 5 & 33.2 & 4.1 & 9 & 33.3 & 3.4 & 14 & 33.3 & 3.5 & 7 & 32.9 & 2.3 \\
\hline 70 Ramus height & 5 & 68.0 & 6.3 & 8 & 67.6 & 5.6 & 13 & 67.8 & 5.6 & 8 & 59.1 & 6.8 \\
\hline 71 Ramus breadth & 5 & 39.2 & 1.6 & 9 & 37.0 & 3.2 & 14 & 37.8 & 2.9 & 8 & 35.5 & 1.8 \\
\hline
\end{tabular}

Man Bac 1 consists of 05M29, 07H1M8, 07H2M27, 07H2M30 and 07H2M32.

Man Bac 2 consists of the other 12 individuals given in Appendix 3.1. 


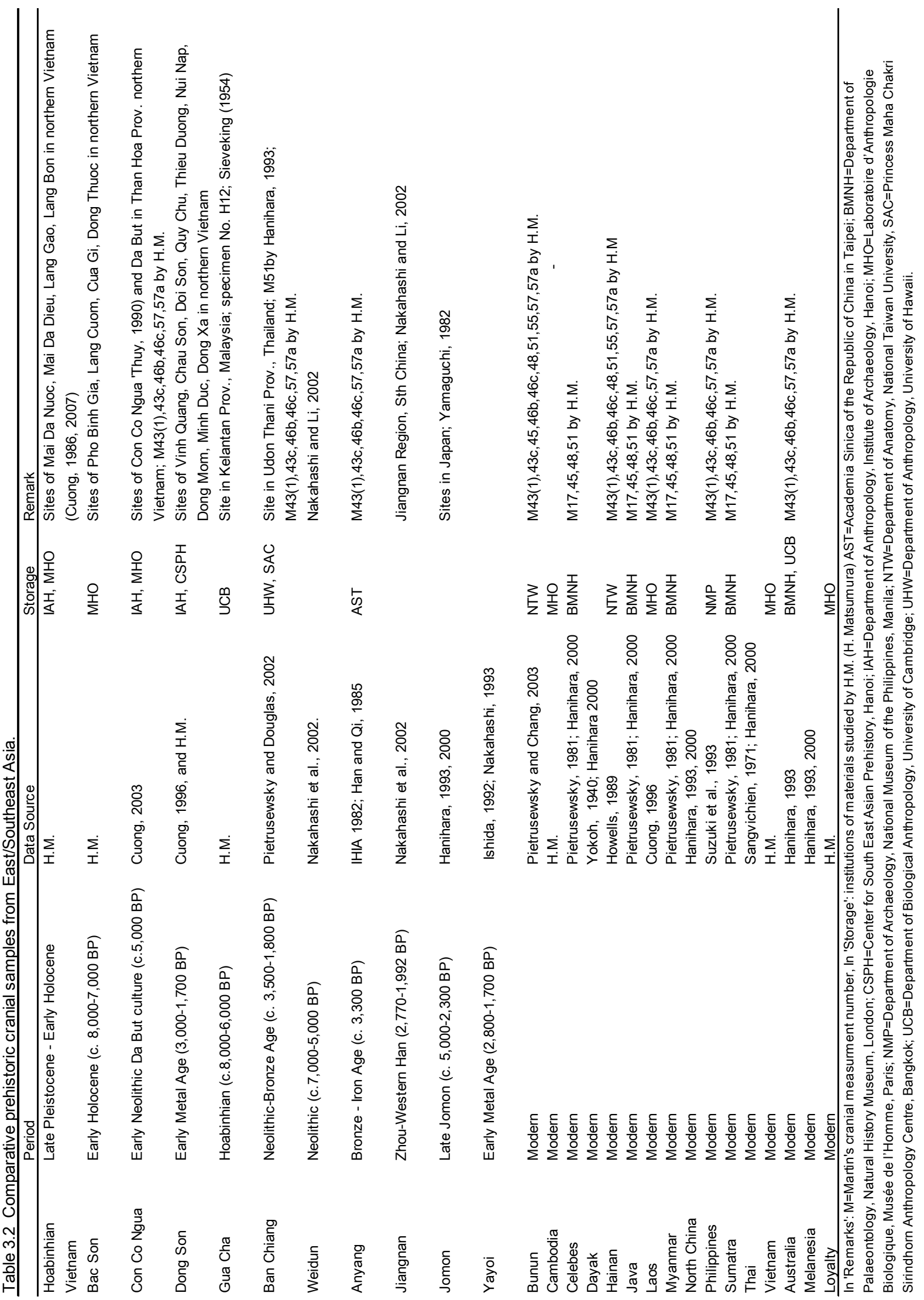




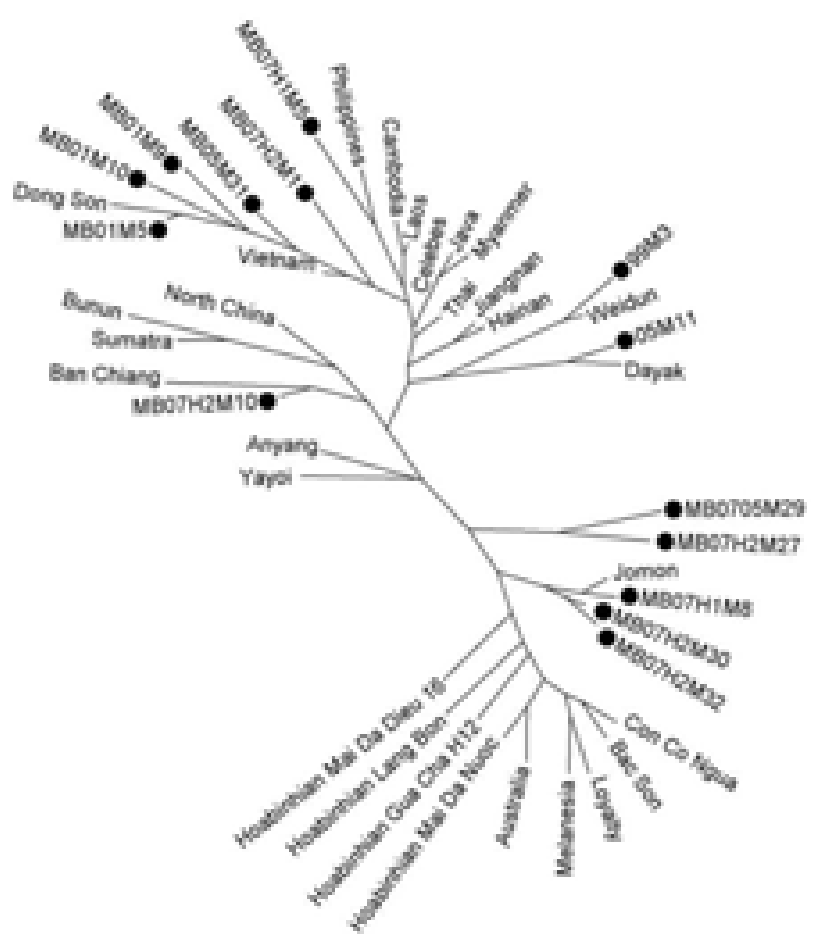

Figure 3.2 An un-rooted tree of neighbour joining analysis applied to the distances of Q-mode correlation coefficients between the Man Bac individuals and comparative samples (based on 9 male cranial measurements).

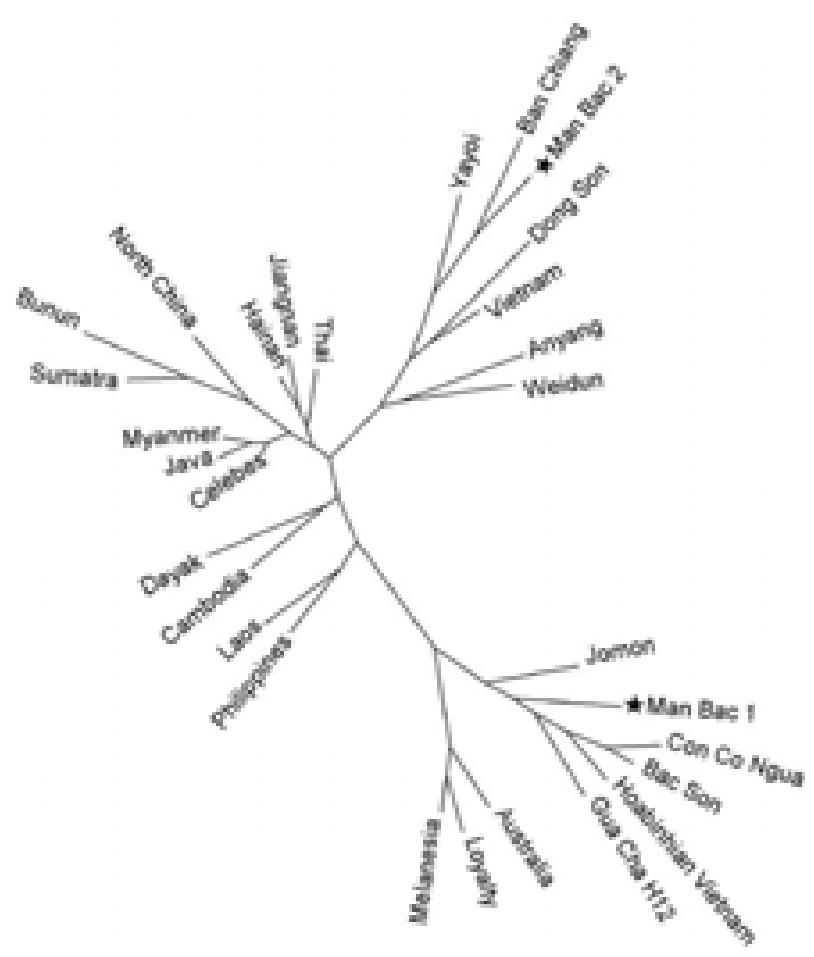

Figure 3.3 An un-rooted tree of neighbour joining analysis applied to the distances of Q-mode correlation coefficients between the two groups of Man Bac individuals and comparative samples (based on 16 male cranial measurements). 


\section{H. MATSUMURA}

\section{DISCUSSION}

Archaeological and linguistic research has linked the dispersal of Austronesian and Austroasiatic language families with the demographic expansion of rice cultivating people during the Neolithic period, and have sought the ultimate homeland of these language and population dispersals in southern China and Taiwan (Renfrew, 1987, 1989, 1992; Bellwood, 1991, 1993, 1996, 1997; Bellwood et al, 1992; Blust, 1996a, b; Glover and Higham, 1996; Higham, 1998, 2001; Bellwood and Renfrew, 2003; Diamond and Bellwood, 2003). With respect to analyses of human skeletal data, the 'Two Layer' model, is instrumental in understanding the population history of mainland Southeast Asia (e.g. Callenfels, 1936; Mijsberg, 1940; Von Koenigswald, 1952; Coon, 1962; Jacob, 1967; Brace et al, 1991, Matsumura and Hudson, 2005; Matsumura, 2006). This model hypothesises that Southeast Asia was initially occupied by indigenous populations, akin to modern Australo-Melanesians, that later exchanged genes with immigrants from North and/or East Asia, leading to the formation of present day Southeast Asian populations. However, some recent cranial and dental studies question this model, alternatively advocating regional continuity or local evolutionary scenarios in order to account for the region's population history (e.g. Turner, 1990; Hanihara, 1994; 2006; Pietrusewsky, 1994, 2005, 2006, 2008). The question arises as to whether these opposing models address the timing and scale of the population dispersal under debate with regard to the expansion of Austroasiatic and Austronesian languages and rice farming cultures, and whether there was a resultant mixture with replacement of extant populations.

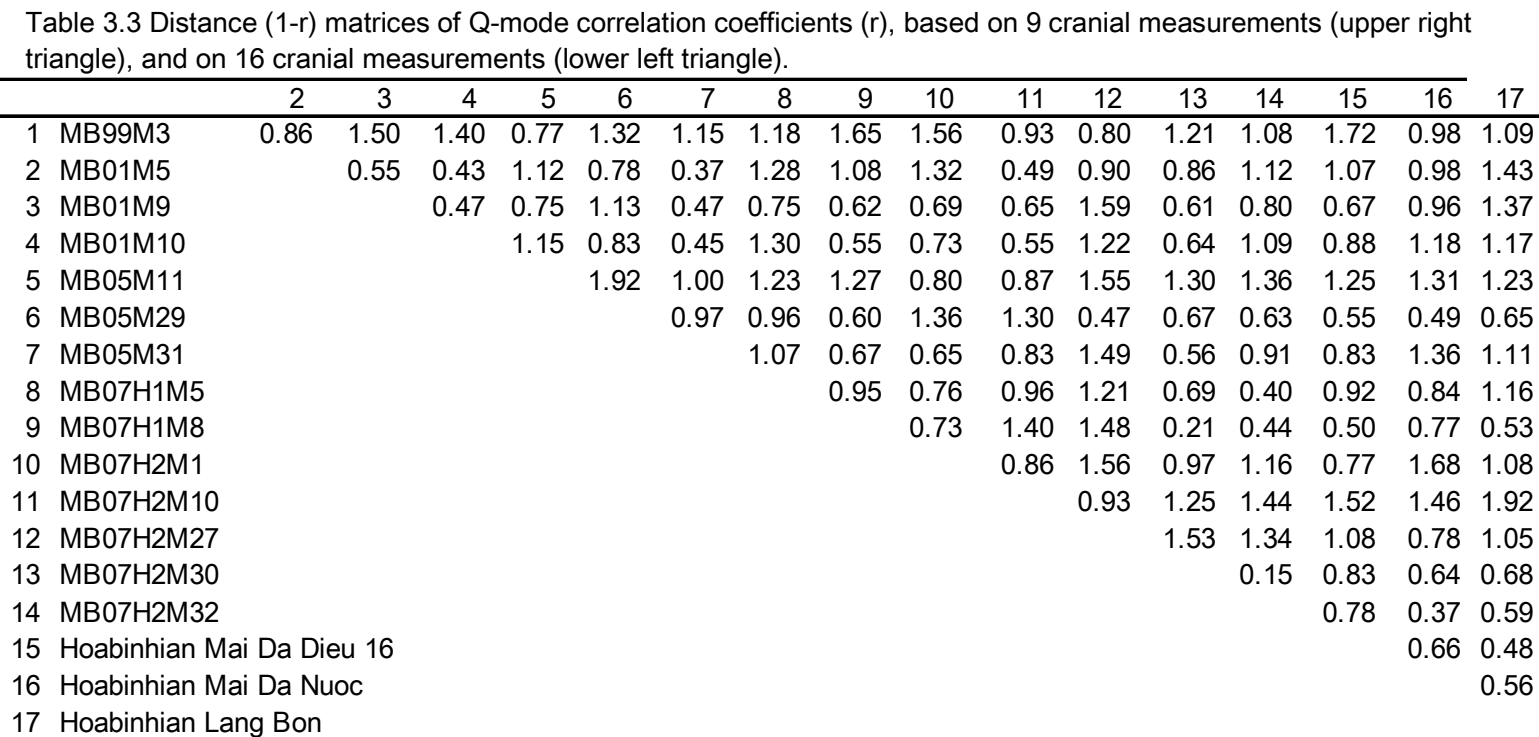




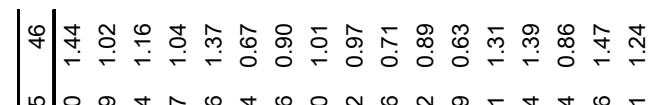

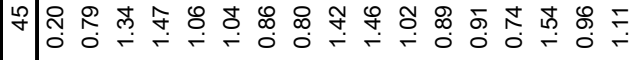

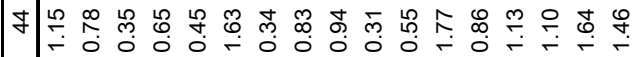

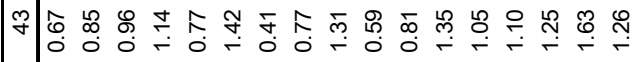
ᄀ

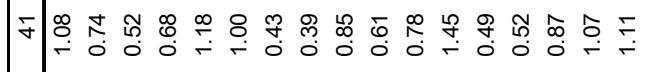

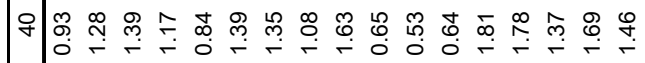

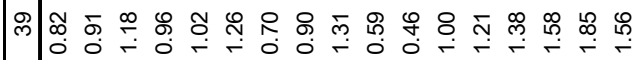

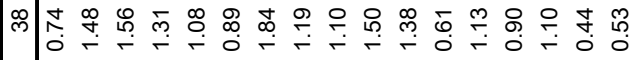

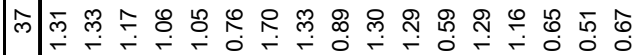

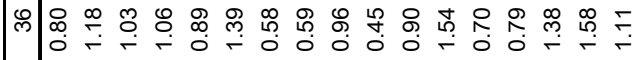

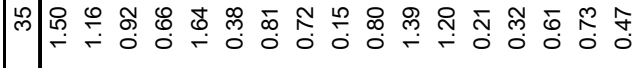

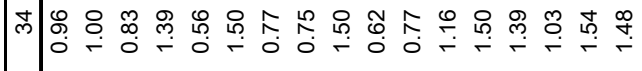

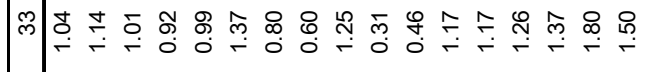

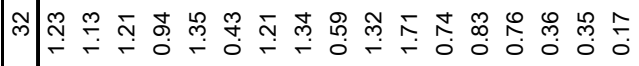

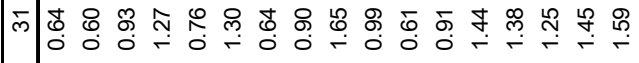

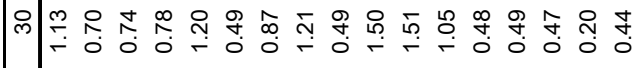

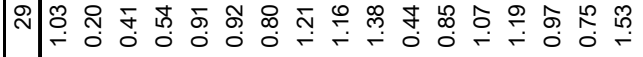
๙

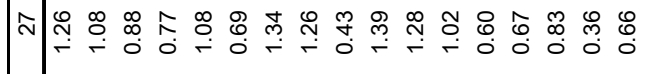

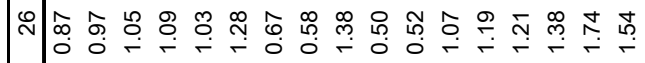

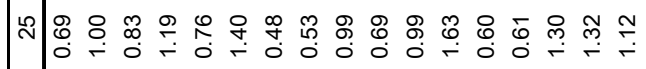

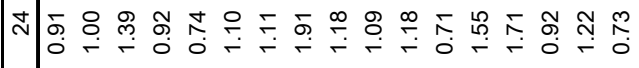
๙

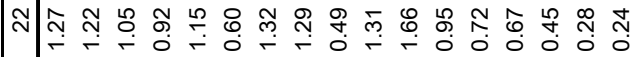

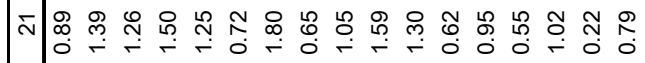

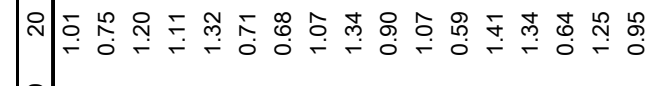

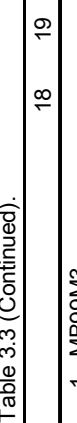

$\stackrel{\circ}{\circ}$ 产 $\frac{O}{2}$ ن.

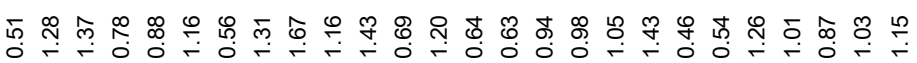

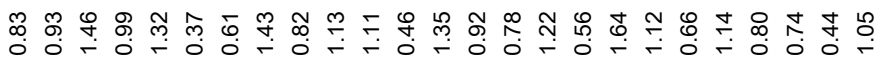

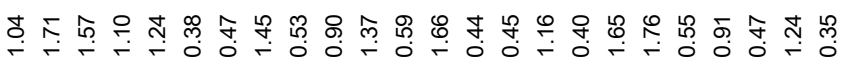

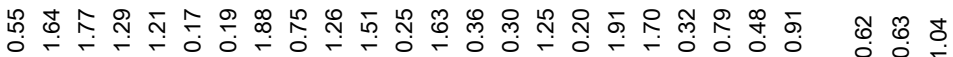

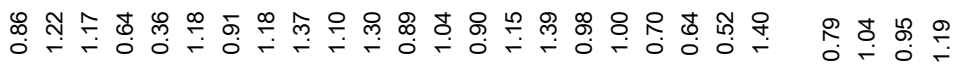

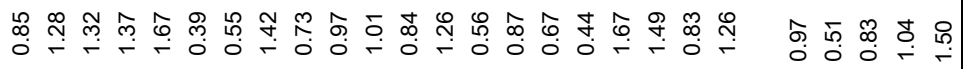

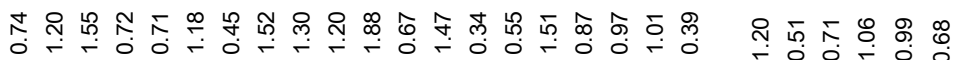

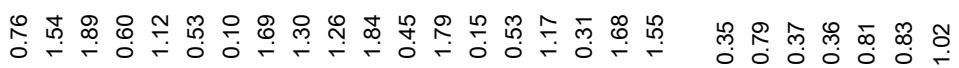

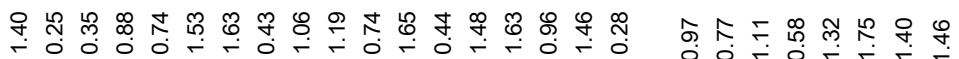

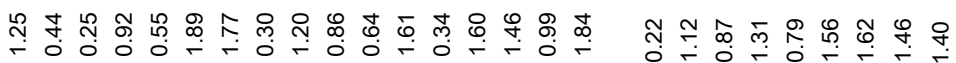

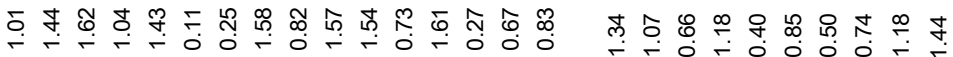

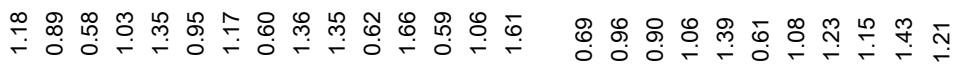

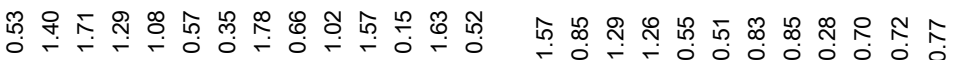

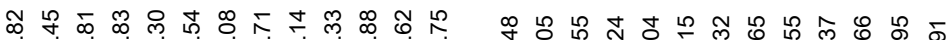

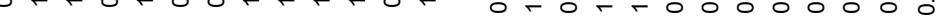
๙

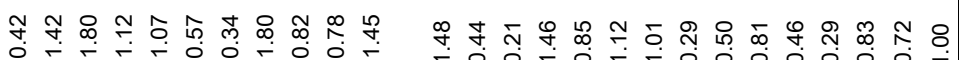

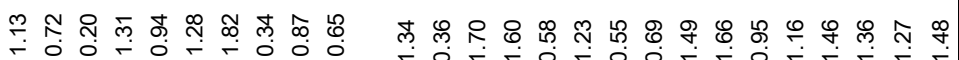

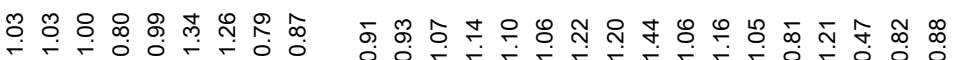

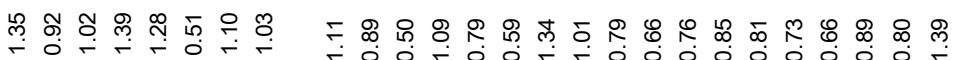

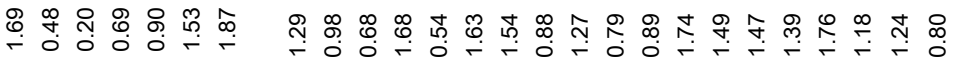

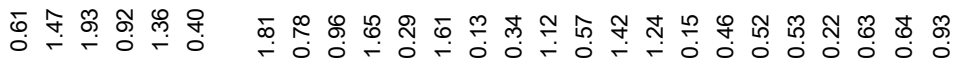

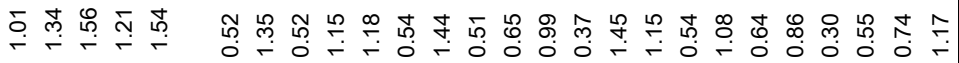

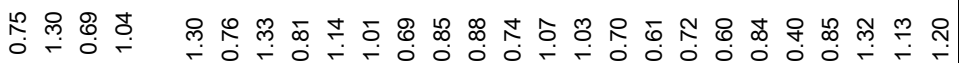

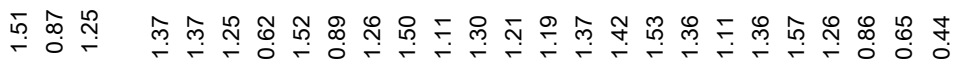

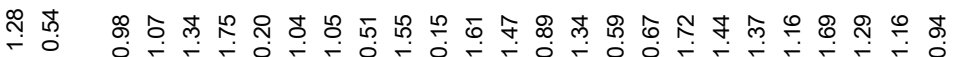

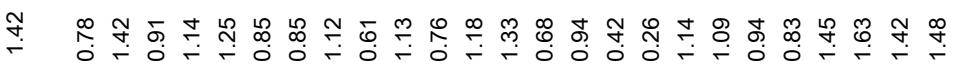

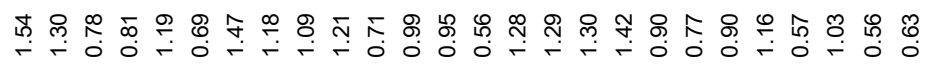

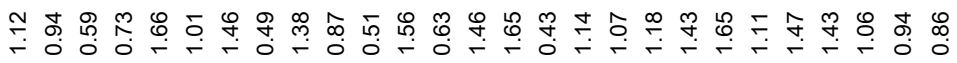

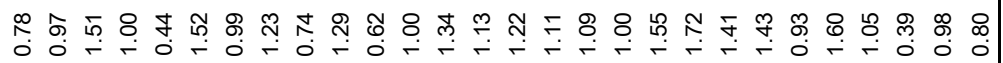




\section{H. MATSUMURA}

With regard to qualitative cranial morphology, the late Pleistocene/early Holocene Hoabinhian and Bac Son samples, in addition to the mid-Holocene Da But individuals, share dolichocephalic calvaria, large zygomatic bones, a remarkably prominent glabella, a concave nasal root and a low and wide face with prominent prognathism. On the other hand, the majority of Metal Period Dong Son individuals tend to possess an array of distinctive cranial features represented by relatively narrow and long faces, flat glabella and nasal roots, and round orbits. Such a remarkable discontinuity in cranial morphology between the pre- and early historic populations suggests that the neolithic period may be regarded as a turning point in terms of the micro-evolutionary history of northern Vietnam, at least. Multivariate analysis using the data set of the craniomorphometric dataset supports the view that Bac Son and Da But populations are direct descendants of Hoabinhian settlers, while much later Dong Son populations owe a significant proportion of their genetic heritage to immigrant populations from the northern peripheral areas of Vietnam, including southern China. In the current analysis it can be seen that the neolithic Man Bac sample is not a genetically homogeneous group. Many Man Bac individuals display cranial features common in the later Dong Son sample, whereas some individuals exhibit characteristics possibly inherited or retained from earlier mid-Holocene and even late Pleistocene Hoabinhian populations. This suggests an initial appearance of immigrants during the Phung Nguyen culture phase currently best characterised, in terms of human biology, by Man Bac, and the coexistence of different population lineages in a single site. The Man Bac specimens lend strong support to the 'Two Layer' model.

\section{SUMMARY}

This chapter has described the quantitative morphology of the cranial series from the Man Bac site. Multivariate comparisons using craniometric data demonstrates that the Man Bac series is clearly not a monophyletic group. Some individuals closely resemble the earlier pre-neolithic settlers of the region, while others show a close affinity to the later Dong Son, or Metal Period, inhabitants. This remarkable intra-group variation in cranial morphology suggests an initial appearance of immigrants at Man Bac with a genetic heritage located in the northern peripheral region of Vietnam, which includes the area currently encompassed by southern China.

\section{ACKNOWLEDGMENTS}

I am grateful for the collaborations of Drs. Ha Van Phung, Nguyen Giang Hai, the Vietnamese Institute of Archaeology, and Dr. Peter Bellwood, Australian National University for the Man Bac excavation projects in Vietnam.

Thanks are also due to Dr. Chris Stringer, Department of Palaeontology, the Natural History Museum, London, Mr. Korakot Boonlop, the Princess Maha Chakri Sirindhorn Anthropology Centre, Bangkok, Dr. Michael Pietrusewsky, the University of Hawai'i, Dr. Nguyen Viet, the Centre for Southeast Asian Prehistory, Hanoi, Dr. Philippe Mennecier, Department Hommes, Musee de 1'Homme, Paris, Dr. Robert Foley, Department of Biological Anthropology, the University of Cambridge, Dr. Tsai 
Hsi-Kue, National Taiwan University, College of Medicine, Dr. Wang Daw-Hwan, IHP, Academia Sinica, Taipei, and Dr. Wilfredo Ronquillio, Archaeology Division, National Museum of the Philippines for permission to study the comparative cranial specimens.

This study was supported in part by a Grant-in-Aid in 2003-2011 (No.15405018, No.20370096, No.18520593, No. 20520666) from the Japan Society for the Promotion of Science, and by the Toyota Foundation (No. D06-R-0035)

\section{LITERATURE CITED}

Bellwood P. 1991. The Austronesian dispersal and the origin of languages. Scientific America 265: 88-93.

Bellwood P. 1993. An archaeologist's view of language macrofamily relationships. Bulletin of the Indo-Pacific Prehistory Association 13: 46-60.

Bellwood P. 1996. Early agriculture and the dispersal of the southern Mongoloids. In: Akazawa T, Szathmàry EJE, editors. Prehistoric Mongoloid Dispersals. Oxford: Oxford University Press. p 287-302.

Bellwood P. 1997. Prehistory of the Indo-Malaysian archipelago, revised edition. Honolulu: University of Hawai'i Press.

Bellwood P, Renfrew C, editors. 2003. Examining the Farming/Language Dispersal Hypothesis. , Cambridge: McDonald Institute for Archaeological Research.

Bellwood P, Gillespie R, Thompson GB, Vogel JS, Ardika IW, Datan I. 1992. New dates for prehistoric Asian rice. Asian Perspectives 31:161-170.

Blust RA. 1996a. Austronesian culture history: the window of language. In: Goodenough WH, editor. Prehistoric Settlement of the Pacific. Philadelphia: American Philosophical Society. p 28-35.

Blust RA. 1996b. Beyond the Austronesian homeland: the Austric hypothesis and its implications for archaeology. In: Goodenough WH, editor. Prehistoric Settlement of the Pacific. Philadelphia American Philosophical Society. p 117-140.

Brace CL, Tracer DP, Hunt KD. 1991. Human craniofacial form and the evidence for the peopling of the Pacific. Bulletin of the Indo-Pacific Prehistory Association 12: 247-269.

Bräuer G. 1988. Osteometrie. In: Martin R, Knussmann K, editors. Anthropologie. Stuttgart: Gustav Fisher. p 160-232.

Callenfels VS. 1936. The Melanesoid civilizations of Eastern Asia. Bulletin of the Raffles Museum Series B, 1: 41-51.

Coon CS. 1962. The Origin of Races. New York: Alfred A Knoph.

Cuong NL. 1986. Two early Hoabinhian crania from Thanh Hoa province, Vietnam. Zeitschrift für Morphologie und Anthropologie 77: 11-17.

Cuong NL. 1996. Anthropological Characteristics of Dong Son Population in Vietnam. Hanoi: Social Sciences Publishing House (in Vietnamese with English title and summary).

Cuong NL. 2003. Ancient human bones in Da But Culture - Thanh Hoa Province. Khao Co Hoc (Vietnamese Archaeology) 3-2003: 66-79 (in Vietnamese with English title and summary).

Cuong NL. 2007. Paleoanthropology in Vietnam. Vietnam Archaeology 2-2007: 23-41.

Diamond J, Bellwood P. 2003. Farmers and their languages: the first expansions. Science 300: 597-603.

Glover IC, Higham CFW. 1996. New evidence for early rice cultivation in South, Southeast and East Asia. In: Harris DR, editor. The Origins and Spread of Agriculture and Pastoralism in Eurasia. London: UCL Press. p 413-441.

Han KX, Qi PF. 1985. The study of the human bones of the middle and small cemeteries of 


\section{H. MATSUMURA}

Yin sites, Anyang. In: Institute of History and Institute of Archaeology IHIA, editor. Contributions to The Study on Human Skulls from the Shang Sites at Anyang Cultural Relics. Beijing: Publishing House. p 50-81 (in Chinese).

Hanihara T. 1993. Craniofacial features of Southeast Asians and Jomonese: a reconsideration of their microevolution since the late Pleistocene. Anthropol Sci 101: 25-46.

Hanihara T. 1994. Craniofacial continuity and discontinuity of Far Easterners in the late Pleistocene and Holocene. J Hum Evol 27: 417-441.

Hanihara T. 2000. Frontal and facial flatness of major human populations. Am J Phys Anthropol 111: 105-134.

Hanihara T. 2006. Interpretation of craniofacial variation and diversification of East and Southeast Asia. In: Oxenham MF, Tayles N, editors. Bioarchaeology of Southeast Asia. Cambridge: Cambridge University Press. p 91-111..

Higham CFW. 1998. Archaeology, linguistics and the expansion of the East and Southeast Asian Neolithic. In: Blench R, Spriggs M, editors. Archaeology and Language II: Archaeological Data and Linguistic Hypotheses. London: Rutledge. p 103-114.

Higham CFW. 2001. Prehistory, language and human biology: is there a consensus in East and Southeast Asia? In: Jin L, Seielstad M, Xiao CJ, editors. Genetic, Linguistic and Archaeological Perspectives on Human Diversity in Southeast Asia. Singapore: World Scientific. p 3-16.

Howells WW. 1989. Skull Shapes and the Map: Cranio-Metric Analysis in the Dispersion of Modern Homo. Papers of the Peabody Museum of Archaeology and Ethnology, Volume 79. Cambridge: Harvard University Press.

Huson DH, Bryant D. 2006. Application of phylogenetic networks in evolutionary studies. Molecular Biology and Evolution 23:254-267.

Institute of History and Institute of Archaeology IHIA, Chinese Academy of Social Science CASS, editors. 1982. Contributions to the Study on Human Skulls from the Shang Sites at Anyang. Beijing: Cultural Relics Publishing House (in Chinese with English summary).

Ishida, H. 1992. Flatness of facial skeletons in Siberian and other Circum-Pacific populations. Z. Morph. Anthrop 79: 53-67.

Jacob T. 1967. Some Problems Pertaining to the Racial History of the Indonesian Region. Utrecht: Ph.D. Dissertation of University of Utrecht,.

Matsumura H. 2006. The population history of Southeast Asia viewed from morphometric analyses of human skeletal and dental remains. In: Oxenham M, Nancy T, editors. Bioarchaeology of Southeast Asia. Cambridge: Cambridge University Press. p 33-58.

Matsumura H, Hudson MJ. 2005. Dental perspectives on the population history of Southeast Asia. Am J Phys Anthropol 127: 182-209.

Mijsberg WA. 1940. On a Neolithic Paleo-Melanesian Lower Jaw Found in Kitchen Midden at Guar Kepah, Province Wellesley, Straits Settlements. Singapore: Proceedings of 3rd Congress of Prehistorians of the Far East. p 100-118.

Nakahashi T. 1993. Temporal cranio changes from the Jomon to the modern period in western Japan. Am J Phys Anthropol 90: 409-425.

Nakahashi T, Li M, editors. 2002. Ancient People in the Jiangnan Region, China. Fukuoka: Kyushu University Press.

Nakahashi T, Li M, Yamaguchi B. 2002. Anthropological study on the cranial measurements of the human remains from Jiangnan region, China. In: Nakahashi T, Li M, editors. Ancient People in The Jiangnan Region, China. Fukuoka: Kyushu University Press. p17-33.

Pietrusewsky M. 1981. Cranial variation in early metal age Thailand and Southeast Asia studied by multivariate procedures. Homo 32: 1-26. 
Pietrusewsky M. 1994. Pacific-Asian relationships: a physical anthropological perspective. Oceanic Linguistics 33: 407-429.

Pietrusewsky M. 2005. The physical anthropology of the Pacific, East Asia: A multivariate craniometric analysis. . In: Sagart L, Blench R, Sanchez-Mazos A, editors. The Peopling of East Asia Putting Together Archaeology, Linguistics and Genetics. Curzon: Rutledge. p 201-229.

Pietrusewsky M. 2006. A multivariate craniometric study of the prehistoric and modern inhabitants of Southeast Asia, East Asia and surrounding regions: a human kaleidoscope ?. In: Oxenham MF, Tayles N, editors. Bioarchaeology of Southeast Asia. Cambridge: Cambridge University Press. p 59-90.

Pietrusewsky M. 2008. Craniometric variation in Southeast Asia and neighbouring regions: a multivariate analysis of cranial measurements. Human Evolution 23: 49-86.

Pietrusewsky M, Douglas MT. 2002. Ban Chiang, a Prehistoric Village Site in Northeast Thailand I: the Human Skeletal Remains. Philadelphia: University of Pennsylvania, Museum of Archaeology and Anthropology.

Pietrusewsky M, Chang C. 2003. Taiwan aboriginals and peoples of the Pacific-Asia region: multivariate craniometric comparisons. Anthropological Science 111: 293-332.

Renfrew C. 1987. Archaeology and Language: the Puzzle of Indo-European Origins. London: Jonathan Cape.

Renfrew C. 1989. Models of change in language and archaeology. Transactions of the Philological Society 87: 103-155.

Renfrew C. 1992. World languages and human dispersals: a minimalist view. In: Hall JA, Jarvie IC, editors. Transition to Modernity: essays on power, wealth and belief. Cambridge: Cambridge University Press. p 11-68.

Saitou N, Nei M. 1987. The neighbour-joining method: A new method for reconstructing phylogenetic trees. Molecular Biology and Evolution 4:406-425.

Sangvichien S. 1971. Physical Anthropology of the Skull of Thai. Bangkok: Ph.D. Dissertation, Faculty of Medicine, Siriraj Hospital, Mahidol University, No.2514.

Sieveking GG. 1954. Excavations at Gua Cha, Kelantan, Part 1. Federation Museums Journal 1: 75-143.

Sneath PH, Sokal RR. 1973. Numerical Taxonomy. San Francisco: WH Freeman and Co.

Suzuki H, Mizoguchi Y, Conese E. 1993. Craniofacial measurement of artificially deformed skulls from the Philippines. Anthropological Science 101: 111-127.

Thuy NK. 1990. Ancient human skeletons at Con Co Ngua. Khao Co Hoc (Vietnamese Archaeology) 3-1990:37-48 (in Vietnamese with English summary).

Turner CGII 1990. Major features of Sundadonty and Sinodonty, including suggestions about East Asian microevolution, population history and late Pleistocene relationships with Australian Aborigines. Am J Phys Anthropol 82: 295-317.

Von Koenigswald GHR. 1952. Evidence of a prehistoric Australo-Melanesoid population in Malaya and Indonesia. Southwestern Journal of Anthropology 8: 92-96.

Yamaguchi B. 1982. A review of the osteological characteristics of the Jomon population in prehistoric Japan. J Anthropol Soc Nippon 90(Supplement): 77-90.

Yokoh Y. 1940. Beiträge zur kraniologie der Dajak. Japanese Journal of Medical Science, Part I Anatomy 8: 1-354. 


\section{H. MATSUMURA}

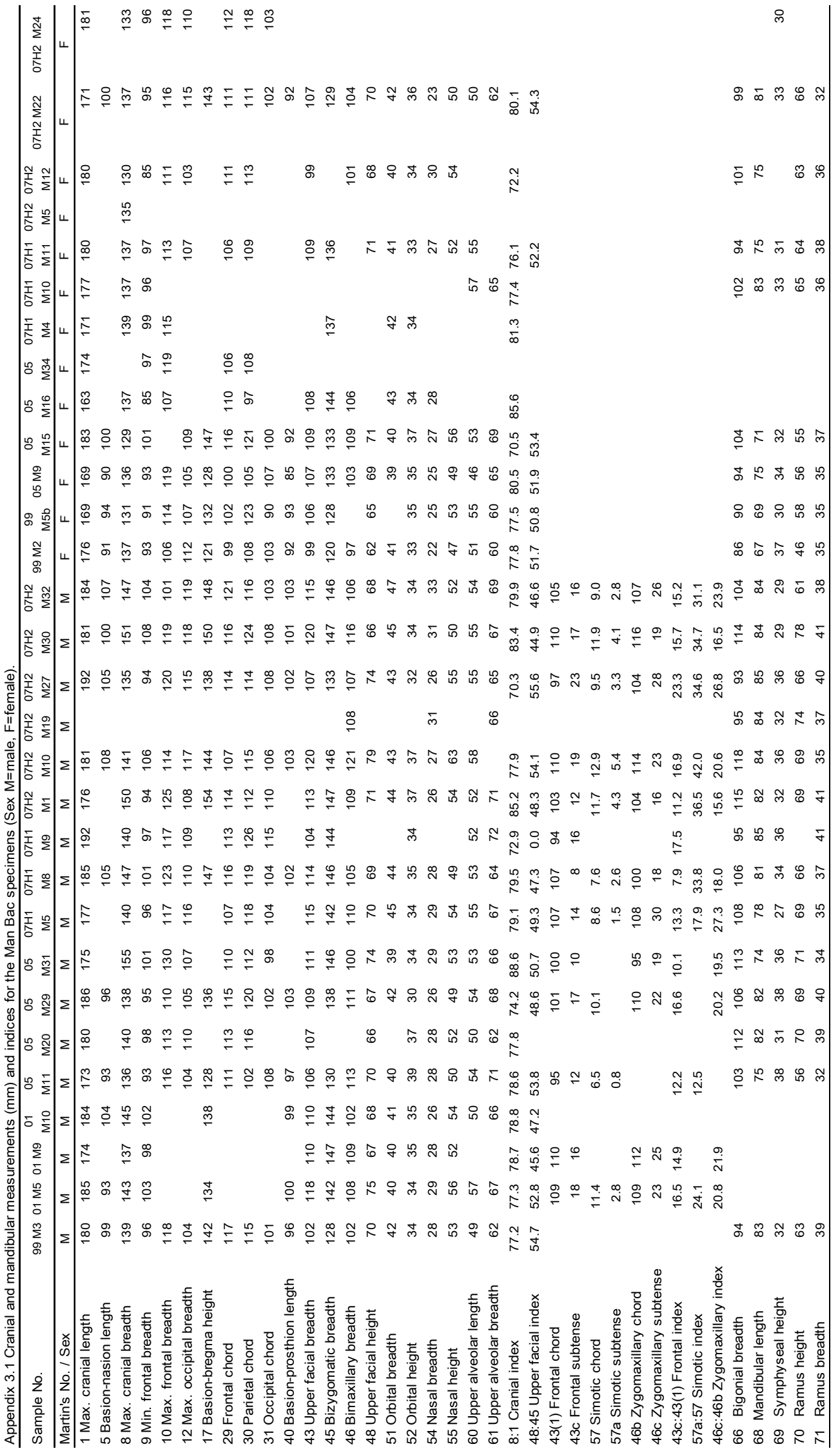

